faunal drift has been ultimately from the IndoMalayan region, with a sprinkling of Australian forms, but whether the Islands were populated by oceanic dispersal or by way of hypothetical land bridges seems difficult to decide, and the author gives the arguments for and against both possibilities. What. ever the origin of the fauna, it dates from not later than early Tertiary times, and as might bo expected isolation has resulted in the dovelopment of a high proportion of species distinctive of the Islands, although between the isolated islands of the group, variations are pronounced only in certain families. Naturally the fauna contains a varied assortment of species, particularly mammals and birds, introduced by man, some, such as the so-called 'native' rats and pigs, probably by the early Polynesian voyagers, and all the other mammals, with the doubtful exception of dogs and mice on somo of the Islands, by white adventurers.

\section{European Rural Life}

A publication of much interest has been produced by the International Institute of Agriculture in Rome. It is entitled "Documentation for the European Conference on Rural Life, 1939", but in spite of its title it contains much of real value and much that has not previously been collected into one volume. Especially valuable is the long chapter on land reclamation and improvement in the different countries of Europe, including statistical informa. tion. This leads to a chapter on the improvement of crops, stocks and rural industries, where again various State efforts aro discussed. In addition, thero are useful summaries of land tenure systems in Europo and a full discussion of the present and potential density of agricultural populations as well as discussion on the economics of farming in different countries. The publication runs to nearly four hundred pages, and has various references to other sources of information.

\section{Music in Mental Diseases}

Dr. Arthur H. Harrington, late superintendent of the State Hospital for Mental Diseases, Howard, Rhode Island, states that in some public institutions in the United States the value of music systematically applied with a therapeutic purpose has been recognized as an aid in institutional activities (Mental Hygiene, 23, 601 ; 1939). Ho has found that though technical instruction for groups of patients has only a very limited value, and does not produce sufficient return for the time and effort expended, mass and group singing of properly selected compositions under proper direction with the psychological aim always in mind, has a definite therapeutic value. Instrumental music of a subdued type seems to have a desirable psychological effect at meal-times, when it produces quiet and repose. In I)r. Harrington's experience the physical act of singing increases a number of bodily functions, stimulates respiration and heart action, gives increased oxygenation to the tissues and often has a favourable effect upon morbid mental states.

\section{Memorandum on Influenza}

Tre Ministry of Health has issued a revised edition of the Memorandum on Influenza, first published in 1919 and revised in 1927 (Memo. H.M. Stationery Office. $2 d$. net). It is pointed out that since the great and fatal pandemic in 1918-19, influenza epidemics in England and Wales have shown a decided preference for the first quarter of the year. The disease is caused by a filterable virus, and the incubation period is about 48 hours. Infection is conveyed from the sick to the healthy by the secretions of the respiratory surfaces. Boyond adequate ventilation, with perhaps gargling with an antiseptic solution after close contact with infection, little can be done for personal protection. At the first feeling of illness, the patient should go to bed in a room by himself, leep warm, and seek medical treatment.

\section{Health Problems of Industry}

THe investigations carried out under the direction of the Industrial Health Research Board, Medical Research Council, during the year ended June 1939 are contained in the nineteenth annual report of the Board, recently issued (H.M. Stationery Office. $6 d$. net). These include a research on the toxicity of various volatile organic substances, now increasingly used as solvents in industry, work on mental integration with special reference to accidents and vocational fitness, and on vocational aptitudes, and researches on the physiological problems of heating and ventila. tion. Environmental conditions, such as lighting and vision, noise and deafness, and the effects on health produced by inhalation of dusts met with in industry, have also been investigated, and summaries of tho results obtained are included in the report.

\section{National Research Council of Japan}

A RECENTLy received report of the National Research Council of Japan (2, No. 8) covers the period April 1938-March 1939. In addition to particulars of the serial publications issued, the report includes summarized accounts of the annual general meeting and of the various divisional and committee meetings, with notes on the thirteenth conference of the International Union of Chemistry and the Tenth International Congress of Pure and Applied Chemistry and other international meetings at which the Council was represented. Besides details of the officers, members and committees of the Council, the report includes a long obituary notice of Baron J. Sakurai by Dr. N. Matsui (see also Nature, Aug. 5, 1939, p. 231), reviewing not only his scientific work but also his work in promoting research activity in Japan and her international cultural relations. Appendixes list serial publications received from abroad and tabulate those of the Council already issued.

\section{Phytopherol: a Standardized Solution of Vitamin E}

VrTAMiN $\mathrm{E}$ is now being manufactured in Great Britain on a commercial scale and has been put within the reach of all by the British Drug Houses, who issue it as capsules of an oily solution containing 
$3 \mathrm{mgm}$. $d l$ - $\alpha$-tocopherol per 5 minims. The booklet issued by this firm contains a brief survey of the chemistry, physiological function, and general clinical applications of vitamin $\mathrm{E}$. It is pointed out that not only may vitamin $\mathrm{E}$ be effective in combating sterility in the female in cases of habitual or threatened abor. tion, but also that types of prognancy toxmia and premature separation of the placenta as well as dysmenorrhwa and vulvovaginitis may also respond favourably to administration. It may be effective in male impotence and may produce descent of ectopic testes. About three pages of the booklet are devoted to a description of work on the relationship of vitamin $\mathbf{E}$ and the anterior pituitary, carried out in the B.D.H. Laboratories by Barrie.

\section{Earthquake near Seattle}

The United States Coast and Geodetic Survey, in co-operation with Science Service and the Jesuit Seismological Association, states that an earthquake was experienced in the State of Washington, U.S.A., on November 13, 1939, at approximately 7h. $45 \mathrm{~m} .49 \mathrm{~s}$. G.C.T. Reports of the earthquake were received from the seismographic stations at Georgetown, Chicago, Fordham, Pasadena, Pittsburgh, Tucson, St. Louis, Butte, Weston, Williamstown, Sitka, College, Philadelphia and Lincoln. From these reports, the epicentre has been calculated to have been near lat. $47^{\circ} 35^{\prime} \mathrm{N}$., long. $123^{\circ} 15^{\prime} \mathrm{WV}$., which is to the west of Bremerton and south-east of Mount Olympus. No damage has been reported. It is well known that the western side of the American continent is more liable to earthquake shocks than the eastern side, though both as regards frequency and intensity the State of California appears to have suffered moro in the past than the State of Washington or any other of the neighbouring States.

\section{The Colonial Service: Appointments and Promotions}

THe following appointments and promotions in the Colonial Service have recently been announced: G. G. Cowley, agrieultural officer, Kenya; C. J. Lawkins, agricultural officer, Nyasaland; M. A. G. Hanschell, agricultural superintendent, Iritish Guiana; J. Paine, agricultural superintendent, Gold Coast; T. A. Phillips, agricultural officer, Nigeria; H. W. T. Webb, agricultural officer, Nyasaland; R. S. T. Bowden, veterinary officer, Malaya; R. A. Hamilton, assistant meteorologist, Nigeria; J.A. Reid, research student, Institute of Medical Research, Federated Malay States; D. L. Blunt, director of agriculture, Nyasaland, to be director of agriculture, Kenya; C. J. NcGregor, agricultural officer, to be senior agricultural officer, Tanganyika Territory.

\section{The Parliamentary and Scientific Committee}

THe Parliamentary Science Committeo has now been re-formed on a new basis and will henceforward be known as the Parliamentary and Scientific Com. mittee. Following a meeting on November 8, it was agreed to form an emergency committee forthwith and to invite all former officers and members of tho executive committee to serve on it. A meeting of this emergency committee was held at tho House of Commons on Wednesday, December 6. Following the resignation of Mr. S. F. Markham as chairman in view of his forthcoming service abroad, Captain L. F. Plugge, M.P., was elected to the chairmanship. Prof. B. W. Holman and Mr. Alan E. L. Chorlton, M.P., will remain as vice.chairman and deputychairman respectively, while the new secretary is Mr. Christopher Powell. It was reported at the meeting that promises of support had been received from a large number of the organizations which previously supported the Parliamentary Science Committeo.

\section{Courses in Technical Optics}

Courses in technical optics, adapted for students with an initial training in physics or mathematics, are now being given as usual at tho Imperial College of Science and Technology, South Kensington. The Technical Optics Section was founded in 1917 to meet the demands of the optical instrument industry and the Services for assistants with an optical training; and although a good many students have taken the course since that time, the present demand exceeds the supply. There aro vacancies for a fow more students who are prepared to begin work at once. The work is of a varied character, embracing many aspects of optical knowledge in its application to industry and to other sciences, and is of great national importance.

\section{Cecil Peace Prize}

A Cecil Peace Prize of $£ 100$ is offered yearly for an essay on some subject connected with the maintenance of international peace, and having some bearing on the principles or work of the League of Nations. It is open to all undergraduates, without distinction of sex or nationality, of any university or university collego in Great Britain or Northern Iroland, who have not attained tho age of twenty-five years on the last day for submitting essays. The subject for the year 1940 is "What wero the reasons for the 'failure' of the League of Nations in the years following 1930; and what steps should bo takon after the present war to strengthen international authority ?" The essay must bo sent to tho Secretary, Universities Bureau of the British Empire, $88 \mathrm{~A}$, Gower Street, London, IV.C.1, so as to arrivo on or before November 1, 1910. Further information can bo obtained from the Secretary.

\section{Institution of Electrical Engineers}

TuE meetings of the Institution of Electrical Engineers will bo resumed in London during the second half of the current session if the present conditions continue. This applies to the ordinary meetings, informal meetings, meetings of the three technical sections and of the London Students' Section. As regards activities in the provinces, the various committees will decide in the light of local conditions whether they are able to carry out programmes of meetings, visits and functions. The first ordinary meeting of the programme for the 